\title{
LETTRE À L'ÉDITEUR
}


ONE C O U L D imagine Andrzej Walicki's contribution * as preceded by a peculiar note: just to warn the reader that this article is a work on the verge of fiction, and the discussed phenomena are either the product of the author's imagination, or are used fictitiously; however, any resemblance to actual phenomena, events or places is not coincidental but entirely intended by the author.

If it were a kind of intellectual game, a cognitive experiment, it could have been an inspiring and refreshing change against so many tedious and indifferent writings. Nevertheless, if it is a game, it has been aimed at clearly political, and not purely cognitive goals. Designed to justify the author's political preferences the image of what has been labelled in the paper as 'Jaruzelski's Poland' is built on persuasion, rather than informative description. 'It is not proper', the author instructs, 'to see it [i.e., Jaruzelski's Poland] as the worst possible evil and to explain its problems in the language of an anti-communist crusade' (p. I90). 'This Poland, Walicki affirms, 'deserves to be seen in the West as a country in which the process of detotalitarianization of "real socialism" is the most advanced' (p. I67). The ruling power should be perceived as 'mild and self-limiting', 'it has abandoned the aim of controlling people's minds' (p. I68). The Jaruzelski's entourage is 'more tolerant, more intelligent and flexible than previous governments in Poland' (p. I67), and 'the Polish authorities should not be accused of being merely puppets of Moscow' (p. rgr).

Walicki's final advise is hardly as original as the above statements for the author simply wants us to believe once more in wholesome effect of the notorious detente policy. Thus, a real possibility of solving or, at least, easing Poland's problems' has to be conceivable, as if, 'only as part international detente' (p. r9o).

\section{Searching for arguments}

Perhaps it is and old-fashioned habit, but when $I$ am instructed what is proper and what is improper, I would expect forceful evidence in order to be convinced. This expectation seems to be the more relevant that in the light of the author's revelations almost all of us have been-and still are-mistaken. Both 'the vast majority of thinking Poles' who 'feel their situation as particularly oppressive', and 'many people in the West' who tend to perceive Jaruzelski's rule the very same way.

Fortunately enough, there are two gentlemen (or three, including Wa-

* Andrzej Walicki, The paradoxes of Jaruzelski's Poland, Archives européennes de sociologie, XXVI (1985), 167-192. 
licki), who realize properly the nature of the order imposed on Poles. It is good to know those few who are in right. However, the intimations of A. Malachowski and Sila-Nowicki must suffice for the whole empirical evidence. Even if Walicki hasty overgeneralizes their impressions to 'Polish intellectuals of the older generation' (paradoxically though, the latter consequently may not belong to the vast majority of thinking Poles!), this measure does not, of course, strenghten his argument.

The thesis regarding de-totalitarianization is as showy, as empirically empty. The author neither tries to name at least some traits constitutive for the totalitarian identity of the order in post-war Poland (and, by the way, it is not certain by itself that it has ever been totalitarian, cf. Kurczewski 1982), nor he dicusses any actual changes which could have such a diminishing effect of this identity.

Of course, the 'return to normalcy' in Poland after December $13,198 \mathrm{r}$, did not mean the restoration-in a literal sense - of the 'old order' prior to the rebellion. It did not mean de-totalitarianization either, but the creation of slightly modified version of a party-state supplemented by a system of institutional-preventive measures. As an impressive illustration may serve the intense legislative activity, establishing a new framework of the social life.

The Sejm adopted more than a hundred legislative acts over the past four years, write Milewski et al. :

Many of them represent a model version of a 'legislation of terror' that introduces into the 'normal' legal system' almost all the regulations of the martial law which was formally lifted in the summer of 1983 . They include, for instance: an amendment of the constitution that give to the Committee of the Defense of the Country the right to establish a state of emergency if the committee alone finds it appropriate; new provisions in the penal code that impose strict sanctions on all people who engage in any oppositional activities, even people who participate in meetings in private homes; a law of the Ministry of the Interior that authorizes the use of the armed forces and of live ammunition under the same conditions as those specified under the martial law decree; a so-called anti-parasite law; and a work-referral law that institutionalizes forced and compulsory labor as a means of worker discipline, political constraint and economic development. The same is true of a juvenile deliquency law that allows the punishment of young people who exercise the right to free assembly; a censorship law modified in order to reinforce strict governmental control of publications and performances; and a law on trade unions that eliminates the workers' right to free association and collective bargaining, and transforms the only officially recognized trade union into a driving belt of the Communist Party. In so, the law in Poland has become openly repressive. It is widely used to justify the use of compulsory force by the state against its citizens [...] People can now be persecuted not because they act directly against the party or communism, but because they violate the existing law. Dura lex sed lex. (r985-86: 342-3; see also Mrela 1986 , for more details).

If the above measures constitute de-totalitarianization (!) it would be the more interesting to learn a particular meaning of the latter term in Walicki's own vocabulary.

And yet, the author goes even further. The regime in Poland which is not only no longer totalitarian has to be also, as if, no longer genuinely 
communistic. It is comforting that at least Walicki knows how to manage along differentiation of genuinely communist and not genuine regimes. It is regrettable that he does not reveal any useful criteria. Thus, the readers must remain rather with their doubts.

Anyway, it is not surprising that in a not genuinely communist country the author observes also a process of de-ideologization. The later means however nothing but gradual abandonment of Marxism. It is hardly the most recent news regarding the status of Maxism in post-war Poland. This time Walicki wants us to believe, first of all, that Marxism has ever been a sole, 'coherent', and 'firm theoretical basis' of the new order. Gently speaking, it is an unbelievable oversimplification. Less gently, it is a mistyfication, since Walicki (who has been for so many years professor in the Institute of Philosophy and Sociology of the Polish Academy of Sciences) knows better than the ordinary dweller in a party-state that its ideological foundations had never been a coherent set of values and beliefs. The most petrified form of the Soviet doctrine which was imposed on the track of the moving westward Red Army, so-called MELS (MarxismEngelsism-Leninism-Stalinism) was 'a cluster of different normative and descriptive components borrowed from different axiologies and tactical declarations. The party-states (including the Polish one) had never implied any clear line of socialist/communist thought, including all possible variants of Marxism' (Kostecki 1985: 3).

Thus, even if Walicki observes the abandonment of Marxist ornamentation, it does not mean, of course, that the 'ideologic state' (Besançon 1976) undergoes an actual de-ideologization. The tactical retouching of current references does not bring about any ideological vacuum (I).

The pretended processes of de-totalitarianization, de-communization, and de-ideologization are supplemented by, as if, 'de-politicization of culture' (p. 180).

Since the sphere of culture is and ever has been a significant component of the system of performing power, 'de-politicization of culture' would mean that the party-state diminished its possession, removing culture beyond the logic of a system! Freedom of association granted to the creative intelligentsia, reinstatement of artistic criteria as governing the cultural activity instead of political ones-beauty is but skin-deep, indeed. Minister Zygulski, called Minister of the Culture Extermination, does not need to care for his future job. For if we look closer, it is only Walicki's peculiar semantics according to which the name's meaning can be detached from the actual sense of the concept it signifies. Thus, the distinction presented by the author is as clear, as hypocritical: while politicization is commitment

(r) Let's compare Walicki's observation to the most recent diagnosis of Milewski et al (1985-86: 343): "Another symptom: the evolution of the official rhetoric, which refers with growing frequency to Marxism-
Leninism, socialism "the leading role of the party" and the "struggle against imperialist subversion" and in the best Stalinist style identifies all opponents with agents of Western secret services'. 
of the creative intelligentsia on the side of the opposition, political commitment on the side of the authorities means de-politicization (!).

The 'politicized de-politicization' is, of course, hardly a new phenomenon in communist Poland, and it may seem strange to ascribe its invention to the present leadership of a party-state.

\section{Legitimacy and reform of the system}

Against the above background the author presents "the main problem of contemporary Poland: a deep legitimization crisis combined with an unprecedented structural economic crisis' (p. r6o). Whilst I am ready to admit that we have to do with two significantly interrelated crisis phenomena, their designation by Walicki may lead to certain doubts.

A legitimation crisis is an elegant occurrence: it can happen to any respectable social-democracy. Habermas (1976), for instance, contends that this is what happens when state intervention is used to preserve the capitalist order. Resorting to methods which disagree with the nature of the order's legitimacy to preserve this order, disturbs its identity and results in a legitimation crisis.

In conditions of a communist order the situation where the authorities resort to measures incompatible with the system's identity in order to reinforce the system (or tolerate such measures), is not at all more surprising. But this is the only simple analogy we can draw. The categories of identity crisis and legitimation crisis and the sense of relation between them are context-bound, which restricts the possibility of using them literally, ignoring concrete historical conditions for which they were originally formulated. An act of depriving these concepts of their contextual connotation is bound to obscure rather than to explain the reality, where conditions specific of the given class of systems do not exist.

In particular, the question is what would mean the concept of legitimation crisis used to interpret the situation in Poland? The crisis of legitimation to appear requires previous existence of legitimation. Thus, could it be a crisis of a phenomenon which never existed in post-war Poland?

Genetically, the very origins of 'People's Poland', which is quite well known, have been founded on violence, and not on legal, traditional or charismatic legitimacy. 'In the beginning there was a certain administrative and power structure and "later" there were attempts to legitimize it' (Rychard 1982). However, the illegitimacy by origins has never been successfully turned into a socially common-as Max Weber could describe it-Legitimitätsglaube: even if the authorities have been-and still are-using scores of concrete legitimizing techniques, invoking diverse grounds and kinds of legitimacy (2). Thus, it seems that in order to

(2) Lamentowicz for instance listed the following methods applied: legitimation doctrine, through sociologically justified 
'domesticate the evil' for the benefit of the Western audience, Walicki would like to forget the birth-mark of the Soviet-type system in Poland.

Referring to the stigma of illegitimacy it is also possible to speak about an illegitimacy crisis, meaning (in no contradiction to a systemic conception of crisis presented by Habermas 1976) a situation in which owing to a lack of legitimization, fewer solutions are possible than are necessary for the system to continue to exist. Although it has existed throughout the entire post-war period, the illegitimacy crisis has varied in intensity: from social apathy and manifested désintéressement for the official order, to temporary permission granted to concrete ruling teams and for concrete undertakings (which did not turn, however, into legitimacy of the power system as an institution); from compulsory involvement, to an open rebellion.

Thus, at the best, what did come into existence during individual periods was a peculiar kind of 'negative legitimacy', i.e. 'a practical compromise between the government and the population which, without accepting the system as a model to follow, appreciates its relative "efficiency" or even "benefitial nature" within a distinctly limited range of practical possibilities, most of which are imposed from outside' (Markus I98I). This kind of compromise did not mean, however, that attempts at changing the status quo ended-they repeated in the form of explosions (3).

Generally, there is a limit to changes which are possible in a given socio-political system. This limit is the system's loss of its identity, a point when it ceases to be this system. Apparently paradoxically, whenever to preserve the system in post-war Poland authorities allowed the use or themselves resorted to the use of means which disagreed with the system's identity, they mitigated the illegitimacy crisis! In this context, a crisis of the system's identity resulting from introducing to it (or allowing the presence of) elements whose logic disagrees with sense of constitutive features of this type of system has been a price paid for averting an open illegitimacy crisis. During different periods this was to be achieved by restoring autonomy to the Church hierarchy, guaranteeing the durability of private farm ownership, allowing the existence of self-dependent trade unions and other organizations independent of the party-state, granting self-management to workers, or the much-publicized 'green light' to private enterpreneurs.

forms (the Party as the best representative), dialectical legitimacy (the Party as the only force capable for resolving conflicts, including those it has started itself), and geopolitical legitimacy (Lamentowicz 198z). Rychard supplemented this list with legitimization through manipulation of national symbols, and comparative presentation of Poland's international prestige, or a greater level of liberalization than in other communist countries. The conviction about "un- changeable order' in Poland or terming the post I 944 situation belong to legitimation methods founded on the stability of the system (Rychard 1982).

(3) It is also possible to refer to a certain evolution of the forms of compromise. In 1956 it was based on 'bilateral conjecture', in $197 \mathrm{I}$ it was unwritten agreement (the famous 'Will you help? Yes, we will!'), in August $\mathrm{I} 980$ it was founded on a formalized social contract. 


\section{KRZYSTOF MRELA}

According to this approach, the system's identity is the scene of struggle to prevent the illegitimacy crisis from reaching a certain limit. This limit results in an open rebellion against the imposed construction of reality, and, at the same time, in 'reorganization' of the system around an alternative set of principles. On the other hand, it is also possible to identify a threshold of the system's identity crisis, the surpassing of which the authorities cannot allow. In other words, regardless of the intensity of the illegitimacy crisis, there is a limit to 'selling out' constitutive features of the communist order. This limit is marked by the communist party preserving political control over collective life. 'In our country, if it is to be socialist normality (even with temporary regression in some fields), only Marxist-Leninist party may be the avant-garde' (Ladosz et al. 1980). This is the same idea articulated in the language of party ideologists.

Thus, the threshold value of the illegitimacy crisis is a state when the organization of society ceases to be constitutive for this order. The threshold value of an identity crisis is a state when this ruling power ceases to be the ruling power.

One could observe that the authorities' reaction to diminishing identity of the order (their endeavours to preserve its identity) is much stronger than their attempts to avoid an open illegitimacy crisis. A strong threat to the system's identity will result in the use of undisguised violence (hence in a further aggravation of the illegitimacy crisis), rather than in averting the illegitimacy crisis at the expense of a further decrease in the system's identity.

In December 13, r981 jargon this meant that the authorities 'will not retreat' and will choose 'the lesser evil' in the form of martial law, even if this were to entail an open rebellion. The authorities will not allow a 'greater evil' in the form of introduction to the system of further elements which would impair its identity, even if this were to mitigate the illegitimacy crisis.

The above conceptual framework allow us to draw some more conclusions regarding systemic determinants of institutional reforms and organizational changes (or, in more general terms: regarding the system's amenability to reform).

Under conditions of the lack of legitimacy, the authorities resort to means which disagree with the system's identity not so much to preserve the system, as to avoid an open illegitimacy crisis. This is to say that the tendency to preserve the order as such is not a sufficient stimulus or reason for change. In fact, this tendency induces petrification of the system and gradual halting of reforms. So, if reforms are initiated at all, the reason is in a situationally enforced tendency to mitigate the illegitimacy crisis. It is no coincidence that all programmes of institutional reforms in postwar Poland were preceded by rebellions.

What is important, a mitigation of the illegitimacy crisis makes it possible to channelize the 'released energy' towards preservation of the system's identity. Since it has been disturbed, the authorities are compelled to 
apply means which enhance this identity. This helps to mitigate the identity crisis of the system, but also aggravates the illegitimacy crisis. In order to prevent an open rebellion in this situation, the authorities again resort to means which disturb the system's identity and... trigger off a new sequence of dependencies.

A division applied by Moskwa (I98 $\mathrm{r}$ ) illustrates a different logic of changes introduced to the system in every cycle, and chances of successful changes. These changes which attempted to violate the existing alignment of social forces through limiting the influence of the central economic administration and the party apparat' (Moskwa 198I: 30) were unsuccessful. Changes succeeded only in the cycle of consolidating (enhancing) the system's identity; when, thus 'made our system resemble that of our neighbors and particularly the Soviet Union [...] which means their aim was to reduce society's influence on socio-economic policy' (Moskwa 1981: 28) (4). The division of changes into 'successful' and 'unsuccessful' clearly corresponds to the difference between formation of the system, and its re-formation.

It is, I believe, also worth noting that the earlier presented sequence of relationships in some way excludes the possibility of a simultaneous identity crisis and an open illegitimacy crisis. This is an important feature of the described cycle. It means, firstly, that bringing about an identity crisis and simultaneously allowing an open illegitimacy crisis, destroys -external in relation to Poles-sources of validity of the group in power. In these conditions the ruling group cannot expect further support either from the centre of power, or from the local leaderships of other member countries of the communist bloc. Secondly, when the two forms of crisis occur simultaneously, they cannot be overcome by conventional methods since under such circumstances it is impossible to manipulate one element to obtain the desired results in the other. As a consequence, an aggravating crisis of the system's identity coupled with an open illegitimacy crisis induces the authorities to use open violence.

In this variant of overcoming the crisis, it is important that violence eliminates the operation of one significant factor, namely avoidance of an open illegitimacy crisis. There is now nothing to avoid: an open illegitimacy crisis could be a reason for, but is above all a direct outcome of the use of violence. In this situation nothing restraints endeavours to consolidate the desired level of the system's identity. 'The reform cycle' has been switched off.

These interdependencies were best exemplified between August 1980

(4) The successful changes Moskwa (I98I) listed included reorganization of the supreme bodies of economic authority and introduction of a new system of planning (in 1949), transformation of workers' councils into conferences of workers' self-management (1958), amending the laws on higher edu- cation after March r968, amendment to the constitution and administrative reform from the I970s. Normalising measures undertaken after the imposition of martial law perfectly fit into this list and at the same time have an updating effect. 
and December 198ז. The institutional revolt and the beginning of the programme of political and economic reform posed a threat to the system's identity, and were nearing the extreme threat tolerable. The design of an economic reform (officially published in July 198I) assigned a new role to the communist party in management of the economy. The reform would strip the party of all but 'moral' or 'normative' power. 'The party influences the economic decisions as party members active in representative bodies convince them of their rightness of stand, and it seeks support from communities which elect representatives' (Kierunki... 1981: 12).

Enterprise self-dependence as designed in the programme would make senseless management hierarchies based on artificial divisions and subdivisions of the economy, and demolish them. Workforce self-management, as envisaged in the concept for remodelling the system would deprive the structures of political control of their domination, and reduce them to the role of instruments in the pursuit of democratically agreed goals of economic activity.

One will readily notice that since December 13,1981 the chief factor which induces reformes, i.e. avoidance of an open illegitimacy crisis, has not been operating (since this crisis could not be avoided anyway as a consequence of imposing martial law). In this situation the tendency to preserve the order's identity (and petrify the established power structures) has been in a sense unrestrained. As the authorities have already chosen the variant of an open illegitimacy crisis to halt the process of disappearance of the order's identity, there is therefore no reason to implement the reform now which would inevitably lead to system identity crisis once again (5).

The only argument for reform left, namely the economic crisis, may serve since then-as it has been already in the past-as an argument for both changes and petrification.

This statement's accuracy is undermined neither by the suspension of martial law at the end of 1982 , not its lifting in July 1983 . These decisions had no 'defreezing' effect and did not restore the rules corresponding to the principles of the reform in their form prior to the decree on martial law (see Mrela and Rychard r982; Mrela 1986). From December 13, 1981 the reform-much-publicized in the mass media-is no longer any major threat to the system's identity. Walicki's belief that 'Jaruzelski's government committed itself to economic reform' (p. I8I) is founded just on 'media power', i.e. on frequently repeated official declarations. (Simultaneously, the author maintains that the authorities in Poland 'has abandoned the aim of controlling people's minds'!). 'Once again'-one could repeat after Ulam (197r: 198)-'more attention is being paid to what the communist are saying than to what they are doing'.

Actually, no real designates are necessary for the reform to sustain its presence in the official propaganda. According to the peculiar formula

(5) The new doctrine does not hide its chief problem: lack of legitimization of power, and that of the now ruling elite.
It seems to play a paradoxical function of drawing legitimization from exposing own illegitimacy! 
adopted in the political life, 'if something has been named, it does exist'. Labelling with the name substitutes on a symbolic level the process of implementation of an actual reform.

It seems, besides, that Walicki would gladly burden the society rather than the authorities with the lack of any spectacular economic progress. The majority of Poles as if opposes the reform attempts, and 'clearly prefer "political justice" to "market justice"' (p. 180). However such a distinction is misleading in the conditions of a communist country where 'separate' market justice simply does not exist. Thus, it is not a phanton of market justice as such, which frightens the Poles, but well grounded conviction that the market under communism is hardly an escape from political injustice.

The markets one could ever observe in post-war Poland have been inherent in the logic of the system. The food coupons market, the market of coupons for durable goods (i.e. the allowances to buy a car, color TVset, refrigerator, etc.), or a market of the U.S. dollar-imitating coupons (enabling to buy products in the hard currency stores), have been induced by the party-state as a secondary effect of doctrinal choices and political arbitrariness-always ideologically rationalized on the basis of justice.

The old-fashioned, self-dependent market as an institution governing itself according to its own rules (and own justice) does not fit to the identity of the Soviet-type system. Being self-dependent, the market 'does not require' the leading role of any party and would eliminate too important sphere of social life from under control of the party-state. It is highly unlikely that Jaruzelski and his entourage-if they are really so intelligent-would voluntarily try to deprive themselves of power over the economy turning it over to the 'anarchy of the market'.

'Facts are stubborn things' as we could see it thus far. Still it would not be difficult to enlarge the list of certain reservations and doubts.

Consequently, how the author knows that the government in Poland is not significantly limited from without and within, but just 'self-limiting'? Perhaps, it is a 'mild government' as compared to the rule of Pinochet, Pol Pot, or even Genghis Khan. However, comparisons of this kind are ahistoric and senseless. The latter three have never been ruling the Polish society in 1980s. And the workers of the Warsaw Steel Mill instead of affirmation for Jaruzelski's 'lesser evil' demanded already in 1982 on their banners: 'Come back, Eddie. Better thief than a murderer' (6).

Perhaps also, the Polish authorities 'should not be accused of being merely puppets of Moscow'. Yet it is not a malicious accusation, and to come to an agreement with Walicki one should ignore what does exist.

(6) Eddie: Edward Gierek, the First Secretary of the Polish United Workers Party in 1970-1980. 
Developments since December 198I indicate, observed Milewski et al, that General Jaruzelski has ignored all major domestic apportunities to work out a compromise between the designs of the Communist rules of Poland and the aspirations of the Polish nation. Increasingly, it has become clear that he has no intention whatsoever of negotiating with Moscow for any concessions on behalf of the Polish people. Two former leaders of the Polish communist party, Gomulka in 1956-59 and Gierek in the early 1970s, manifested at least some willingness to exploit a potential flexibility on the part of the Soviet Union with respect to Eastern Europe [...] So far, it seems that General Jaruzelski merely seeks support and legitimacy from Moscow for the 'normalization' policy (1985-86: 35I).

It may seem astonishing that in order to show the evil in today's Poland as a lesser one, Walicki resorts to the impressive variety of measures suitable to propaganda rather than to search for meaningful facts. The author's main attempt has been, however, in spreading out certain ideology: the ideology of 'the lesser of two evils', which is as old as the Soviet-type system in Poland. Explicite or implicite, it served from the very beginning as a peculiar rationalization (simultaneously a threat and an excuse) for the benefit of the incapacitated society.

Since the imposition of martial law, the concept of a lesser evil has been called by its name and the offered 'operationalization' showed clear connection-as Lamentowicz pointed it out-with singularily conceived economics of measures applied: "A Polish tank is better than a foreign one, internment is better than arrest, tear gas is better than truncheon' (quoted after Pankow 1983).

Undoubtedly, the concept of a lesser evil offers an ideology of stupefying self-contentment and passivity. There is no need for any action since the evil, thank heaven, is lesser than the worst possible one. What stupefies is that an actual evil is always lesser than the one which might happen and/or may happen. As Poles used to say: 'It is never so bad that it could not be worst'.

Walicki's presentation of Jaruzelski's rule as the lesser evil is, thus, somewhere between failure in empirical evidence and triviality (as far as the lesser evil is better than the worst one).

Founded on such a doubtful ground any Western policy in dealing with Jarulzeski's regime would lack an elementary prudence. The West can hardly afford to play still a passive role of a "legitimizing instance" after each case of suppression in Eastern Europe, and under the pretence that the choice has been made between the lesser and the greater evil. That is a role in the Soviet scenario rather than a self-dependent international policy. For the latter to begin, one has to face the facts as they are, regardless whether they may seem as better or worst, lesser of greater.

KRZY S T OF M R E L A 
$R E F E R E N C E S$

Besançon, A., Court traité de soviétologie d' l'usage des autorités civiles, militaires et religieuses (Paris 1976).

Habermas, J., Legitimation crisis (London, Heinemann, I976).

Kierunki..., Kierunki reformy gospodarczej (Directions of the economic reform) (Warszawa, nakladem 'Trybuny Ludu', I 98 I).

KostвскI, M.J., Between the gospel and politics: changing relations between the Roman Catholic Church, part/state, and society in post-war Poland. Paper presented to the $\mathrm{r}_{9} 8_{5}$ meeting of the Society for the Scientific Study of Religion, Savannag, Georgia, 1985 .

KuRCzEwski, J., The old system and the revolution. Sisyphus. Sociological Studies, Vol. III: Crises and conflicts: the case of Poland $\pi 980-81$ [Warsaw: PWN] (1982), $21-$ 32.

LAdosz, J., R. Karpinski and J. KurowICKI, W sprawie programu parti (On the party program), Gazeta Robotnicza, $18 \mathrm{De}-$ cember, 1980 .

Lamentowicz, W., Kryzys legitimizacji wladzy politycanej w powojennej Polsce (Legitimation crisis of political power in postwar Poland) (Warszawa 1982), typescript.

Markus, M., Crisis of legitimization: understanding Poland. Thesis Even, 3 (1981).
Milewski, J., K. Pomian and J. ZieLONKA, Poland: four years after. Foreign Affairs, LXIV (1985-86) 2, 327-359.

Moskwa, A., Udane proby nieudanych reform (Successful attempts at unsuccessful reforms), Wektory, I (I98I), 28-30.

Mrela, K., System's identity crisis: revolt and normalization in Poland, Crises in Soviet-type Systems, Study No. 12 [Vienna] (1986).

MrelA, K., A. Rychard, Samorzadnosc w praktyce (Self-management in practice), in A.K. Kozminski (ed.), Reforma gospodarcza $w$ praktyce (Economic reform in practice. Research report), Warszawa, TNOIK (1982), pp. 4-30.

Pankow, W., Stan wojenny w Polsceciaglosc czy zmiana systemu wladz (The martial law in Poland. Continuity or change of the system of power ?) (Warszawa I983), typescript.

RychaRd, A., Prawomocnosc a stablinosc ladu spolecznego (Legitimacy and stability of the social order) ( 1982 ). Paper prepared at the 6th EGOS Colloquium, Florence, Italy, 3-5 November 1983 .

Ulam, A.B., The Rivals. America and Russia since World War II (New York, Penguin Books, 1971). 